\title{
SCS427 Elenise: late-ripening apple variety of good storability and resistance to Glomerella Leaf Spot
}

\author{
Frederico Denardi', Marcus Vinícius Kvitschal' ${ }^{1}$ Maraisa Crestani Hawerroth' and Luiz Carlos Argenta'
}

\begin{abstract}
SCS427 Elenise' (parents: Imperatriz and Cripps Pink) was released for being an apple variety resistant to Glomerella Leaf Spot, for producing red apple with late maturation, with high conservation capacity and pulp texture equivalent to the fruit Cripps Pink's parent, but with less acidic flavor. It represents the opportunity to extend the harvest window and offer the market high quality apples throughout the inter-harvest period.
\end{abstract}

Index terms: Malus x domestica Borkh.; breeding; diseases resistance; time of ripening; fruit storability.

\section{SCS427 Elenise: macieira de maturação tardia, boa conservação e resistente à Mancha Foliar de Glomerella}

Resumo - A 'SCS427 Elenise' (parentais: Imperatriz e Cripps Pink) foi lançada por ser resistente à Mancha Foliar de Glomerella, produzir maçãs vermelhas e com maturação tardia, com alta capacidade de conservação, e textura de polpa equivalente aos frutos do parental 'Cripps Pink', porém de sabor menos ácido. Representa a oportunidade de estender a janela atual de colheita e oferecer ao mercado maçãs de alta qualidade ao longo do período de entre safra.

Termos para indexação: Malus $x$ domestica Borkh.; melhoramento genético; resistência às doenças; época de colheita; conservação dos frutos.

\section{Introduction}

The availability of commercial apple varieties of adequate fruit quality to attend the expectations of Brazilian market is restricted in Brazil (KVITSCHAL et al., 2019). Currently, up to $94 \%$ of the Brazilian apple production comes from the varieties Gala and Fuji and their colored sport mutations (FACHINELLO et al., 2011). It makes fruit handle a more challenging practice due to the high demand for labor and apparatus for harvesting, transportation and storage room loading in a short period. However, in most microclimates, where apples are grown in southern Brazil, the winters are shorter and growing seasons are longer than those in most traditional temperate-zone apple producing countries. So, there are fewer chilling hours' accumulation, limiting the cultivation of apple varieties with high chilling requirement. On the other hand, it is possible to extend the apple-harvesting season in subtropical climate regions. So, it is possible to offer varieties that attend to a wide spectrum of fruit ripening, with picking time from one month before Gala apples by using varieties of local low chilling requirement to at least one month after the ripening of late apples like Fuji (SEZERINO et al., 2018).

Gala traditional sport mutations are very susceptible to the most important pathogens present in apple orchards of southern Brazil, including Glomerella Leaf Spot (Colletotrichum spp.) (FURLAN et al., 2010), whose severity has enlarged in the last years, increasing production costs per unit. The breeding for new varieties resistant to diseases is the cheapest and the most efficient alternative to prevent pathogen damages and has been the goal of apple breeding programs worldwide in the last decades (SANSAVINI et al., 2004).
The research on apple breeding at Epagri has aimed at the development of new varieties better adapted to the local climate and with a better spectrum of resistance to the main local diseases (DENARDI et al., 2019). Also, enlarging the picking time by offering new apple varieties of fruit ripening later than Fuji's ripening can be an effective opportunity to extend the current 2.5 months of Gala and Fuji harvest period to, at least, 4.5 months. However, these late fruit ripening varieties must have long fruit storability, in order to offer high quality apple fruits in terms of flavor and flesh texture to the consumers over the offseason. In this sense, the Epagri's Apple Breeding Program developed the new apple variety SCS427 Elenise that adds many of these characteristics, and with high resistance to Glomerella Leaf Spot. Its fruits ripe later in the season as the 'Cripps Pink' parent, have red skin color, excellent flavor, flesh texture

Recebido em 5/11/2019. Aceito para publicação em 13/2/2020.

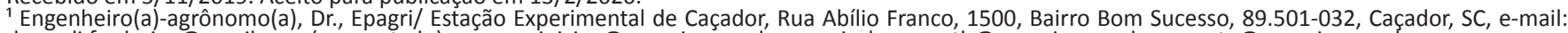
denardi.frederico@gmail.com (aposentado), marcusvinicius@epagri.sc.gov.br, maraisahawerroth@epagri.sc.gov.br, argenta@epagri.sc.gov.br. 
and very good fruit storability. Fruit of SCS427 Elenise has high sugar and acid content which enhance its flavor. 'Cripps Pink' fruit is also recognized by the outstanding flavor, although it can be rated as too acid to most of Brazilian apple consumers, especially at harvest season moment.

\section{Origin and breeding methodology}

The cross that originated 'SCS427 Elenise' was made at Epagri in 2001 and involved the varieties Imperatriz $(+)$ ) and Cripps Pink $\left({ }^{\lambda}\right)$, as presented in Figure 1. The main objective of this cross was to join the low to moderate chilling requirement, good adaptation to the mild winters of Midwestern region of Santa Catarina state and resistance to Glomerella Leaf Spot (Colletotrichum gloesporioides) from the 'Imperatriz' parent to the high fruit quality based on flavor, skin-color and storability from the another parent, 'Cripps Pink'. The artificial hybridization, collecting and germination of the seeds, and the initial cultivation of the seedling populations in the nursery were as previously described by Denardi et al. (2013). The preliminary evaluations for diseases resistance, precocity of fruiting, as well as the advanced evaluation for local climatic adaptation and fruit quality on dwarfing rootstock also followed the methodology described by these authors. The evaluations for Glomerella Leaf Spot resistance were performed through artificial inoculation, as described by Furlan et al. (2010).

The segregating population was constituted by 602 seedlings, 232 of which were chosen to be grafted on M.9 rootstock (one tree per pre-selection) aiming to evaluate agronomic traits and fruit quality on orchard located at Epagri/Caçador Experimental Station. The most promising selections were grafted on the rootstock G.814 subsequently and carried out on trials for advanced studies at Epagri, Caçador Experimental Station and at Fischer S/A
Agribusiness Company, in Fraiburgo, at the Midwestern of Santa Catarina. These studies were performed under an experimental randomized block design of four replicates with four trees per plot, at a spacing of $1.5 \mathrm{~m}$ between plants and $4.0 \mathrm{~m}$ between rows $(1,666$ trees per hectare), including Galaxy and Fuji Suprema varieties that were used as controls. At this stage, it was evaluated the tree vigor, the bud break potential in local climatic conditions, the phenology of flowering and fruit ripening, the yield (kg per tree) and the fruit weight (g), according to the methodology described by Denardi et al. (2013). About post-harvest studies, apple fruits of 'SCS427 Elenise' and 'Cripps Pink' were harvested 218 and 215 days after full bloom, respectively, and assessed for maturity and quality at the harvest (day zero) and after storage, as described in Argenta et al. (2013) and Argenta et al. (2018). All fruits were cooled at $1^{\circ} \mathrm{C}$ in 36 $\mathrm{h}$ after harvest and stored in controlled atmosphere conditions - CA (1.5 $\mathrm{kPa} \mathrm{O}_{2}$, $<0.5 \mathrm{kPa} \mathrm{CO}$ ) at $0.7^{\circ} \mathrm{C}$.

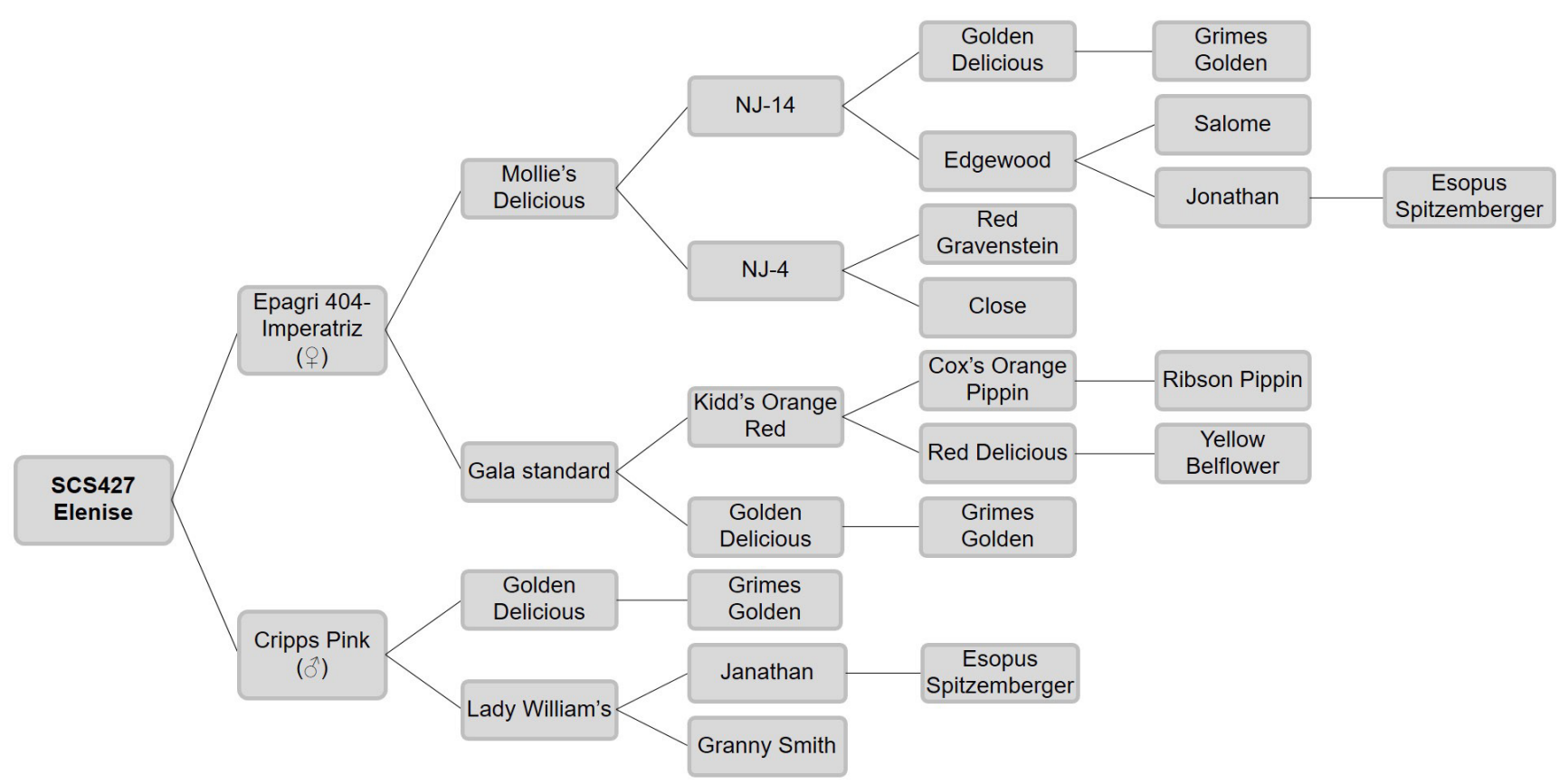

Figure 1. Pedigree of the apple variety SCS427 Elenise. Occasional absence of the second parent is due to the lack of information reported in the literature available

Figura 1. Genealogia da variedade de macieira SCS427 Elenise. A ausência ocasional do segundo genitor é devida à falta de informação relatada na literatura disponível 


\section{Description, perspectives} and shortcomings

Based on trunk cross sectional area (TCSA), 'SCS427 Elenise' is similar to 'Galaxy' regarding to the vigor, but less vigorous than 'Fuji Suprema' (Table 1). Its growing habit is quite similar to the 'Cripps Pink' variety, with tendency to upright branches, requiring a good management of the trees. The chilling requirement of 'SCS427 Elenise' is moderate, indicating a slightly better bud-break potential score to local climate in comparison to 'Galaxy' and 'Fuji Suprema'. Nevertheless, it is necessary to use chemicals to induce bud-break after dormancy of 'SCS427 Elenise' in this region. The blooming period of 'SCS427 Elenise' has full coincidence with that of 'Galaxy' and a few days later than that of 'Fuji Suprema'.

'SCS427 Elenise' is similar to 'Galaxy' on precocity of fruiting, but more precocious than 'Fuji Suprema' based on the intensity of blooming and fruiting on one-year-old branches of young trees (data not shown). This has a positive effect on the payoff of initial costs for orchard planting and on the cumulative yield of the orchards. 'SCS427 Elenise' presents a great ability to differentiate flowering buds on brindles, even showing upright growing habit that requires correct canopy managing in order to maintain good equilibrium between the vegetative and the reproductive development. When cultivated on the rootstock G.814 in the Midwestern of Santa Catarina, 'SCS427 Elenise' showed yield similar to 'Galaxy' and 'Fuji Suprema' (Table 1) along four crop seasons and for cumulative yield (from 2011/12 to 2014/15), so it has a good yield potential for Brazilian conditions. However, it is very important a good management of thinning because it has been observed some biennial bearing in some orchards with 'SCS427 Elenise'.

According to artificial disease inoculation tests, 'SCS427 Elenise' showed high resistance to Glomerella Leaf Spot (Colletotrichum gloesporioides), being this trait one of the main advantages of this variety for growing in Brazil, where this disease is very aggressive and damaging on

Table 1. Agronomic characteristics of the apple varieties SCS427 Elenise, Galaxy and Fuji Suprema grafted on the rootstock G.814, cultivated in Fraiburgo County, at the Midwestern of Santa Catarina state, Brazil

Tabela 1. Características agronômicas das variedades de macieira SCS426 Elenise, Galaxy, e Fuji Suprema enxertadas sobre o portaenxerto G.814 cultivadas no município de Fraiburgo, na região meio-oeste do estado de Santa Catarina, Brasil

\section{Statistical data of comparative values, subjected to statistical analysis}

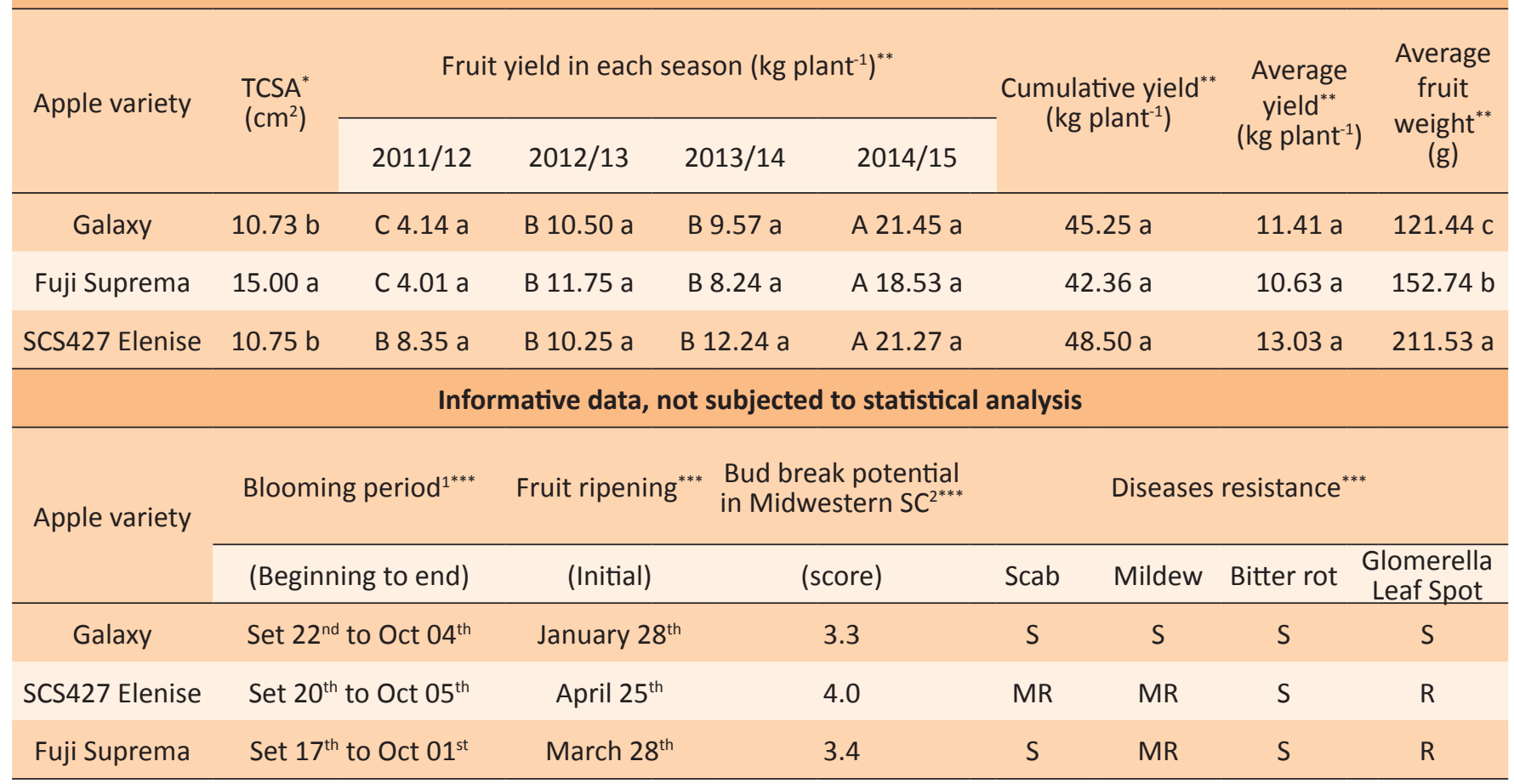

Averages followed by the same uppercase letter in the row and lowercase letter in the column do not differ from each other by the Scott-Knott test at $5 \%$ error probability. Analyses performed using the Sisvar Statistical Program (Ferreira 2011).

*TCSA: Trunk cross sectional area measured at $5 \mathrm{~cm}$ above the grafting point for the 2014/2015 growing season.

**Data collected over four seasons (from 2011/2012 to 2014/2015).

${ }^{* * *}$ Data collected over three seasons (2012/2013, 2013/2014 and 2014/2015).

${ }^{1}$ Considering the beginning when the plants showed $5 \%$ of blooming; full when $70 \%$ of flowers were open, and end of blooming when most of petals fell.

${ }^{2}$ Numerical scale, where 1 corresponds to sprouting of only the apical buds of branches and 5 represents the sprouting of all buds (vegetative and floriferous), in response to chemical treatment to overcome the dormancy of buds with $3.5 \%$ mineral oil and $0.7 \%$ hydrogenated cyanamide.

R: resistant, MR: moderately resistant, S: susceptible. 


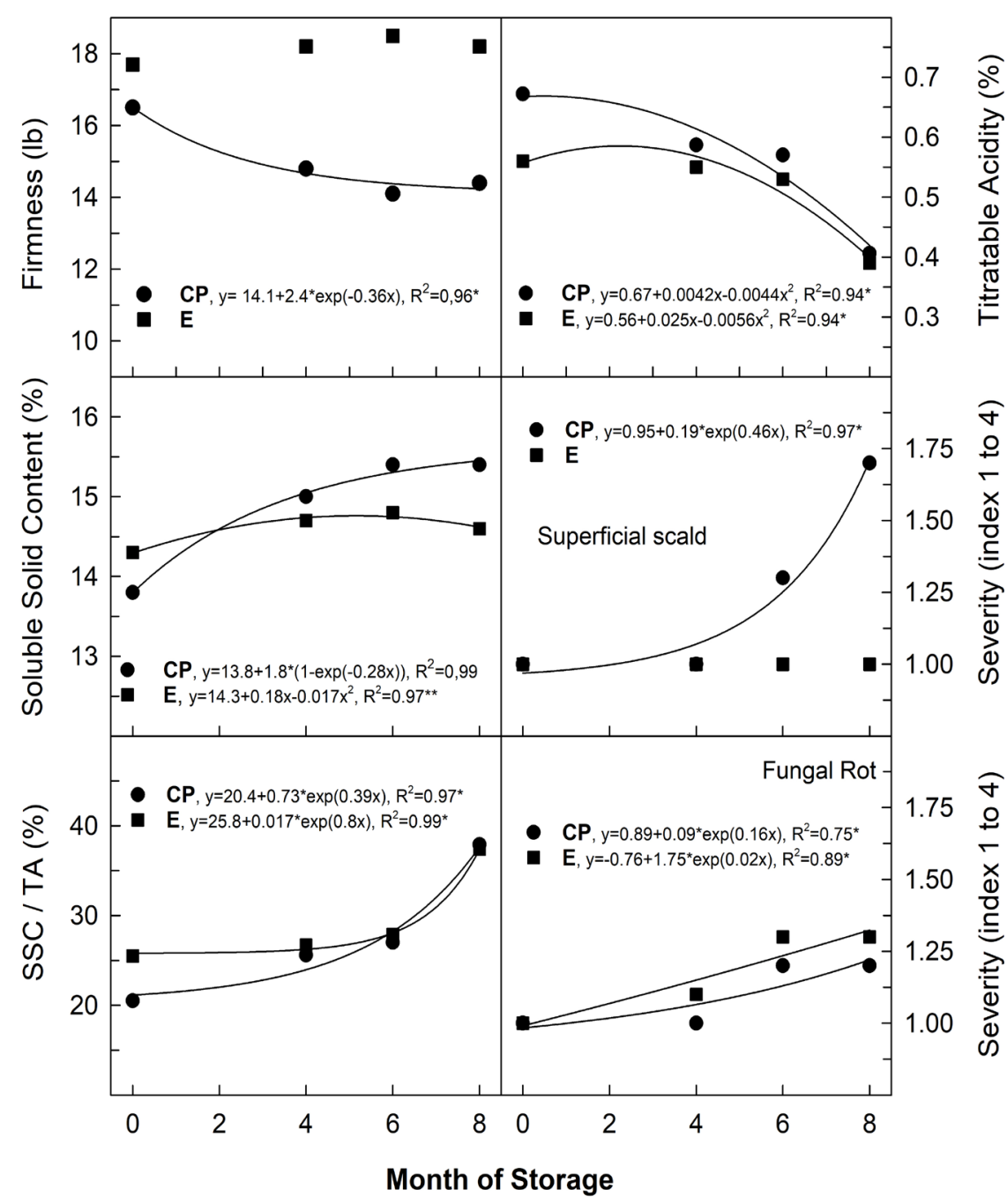

Figure 2. Changes of flesh firmness, titratable acidity, soluble solid content, severity of the superficial scald and fungal rots as a function of storage period and variety (E: SCS427 Elenise, CP: Cripps Pink). Data represent averages of four 20 -fruits replicates $(n=4)$. Fruits were assessed one day after harvest and after 7 days at $22^{\circ} \mathrm{C}$ in regular air, following 4 to 8 months in controlled atmosphere storage $\left(0.7^{\circ} \mathrm{C}\right)$. Only significant $(\mathrm{p}<0.05)$ regression models are presented

Figura 2. Alterações na firmeza da polpa, acidez titulável, teor de sólidos solúveis, severidade da escaldadura superficial e podridões fúngicas em função do período de armazenamento e da variedade (E: SCS427 Elenise, CP: Cripps Pink). Os dados representam médias de quatro réplicas de 20 frutos $(n=4)$. Os frutos foram avaliados um dia após a colheita e após 4 a 8 meses de armazenagem em atmosfera controlada a $0.7^{\circ} \mathrm{C}$ mais 7 dias em atmosfera do ar a $22^{\circ} \mathrm{C}$. Apenas modelos de regressão significativos $(p<0,05)$ são apresentados

susceptible varieties (ARAÚJO et al., 2016). It is moderate resistant to Apple Scab (Venturia inaequalis), although it is not immune. 'SCS427 Elenise' is tolerant to Powdery Mildew (Podosphaera leucotricha), but it is susceptible to Bitter Rot (Glomerella cingulata).

The fruit ripening on the trees begins approximately at the same time a good choice for growers to extend the period for harvesting apples in Brazil. The fruit skin color is mid-dark red-pink over a green-yellowish background on a bicolor standard, resembling 'Cripps Pink' parent. The fruit shape is globose to cylindrical and the size is larger than 'Galaxy' and 'Fuji Suprema' (Table 1). The fruit flesh is cream white, firm, crispy and very juicy. The flavor is sweetsub-acid, being less acid than 'Cripps Pink' along the first four months after harvest, getting well-balanced flavor after this period in CA cold storage.

According to post-harvest trials data (Figure 2), the starch degradation indexes (1-9 scale) of 'SCS427 Elenise' (4.5 \pm 1.1$)$ and 'Cripps Pink' (3.5 \pm 1.2$)$ apple fruits are not different when both were harvested at the same day, indicating they were quite similar in maturity stage. The soluble solid content (SSC) in 'SCS427 Elenise' fruits was higher at harvest and remained more constant than its 'Cripps Pink' parent along 8 months in CA cold storage. However, 'SCS427 Elenise' showed higher flesh firmness and lower titratable acidity than 'Cripps Pink' at the harvest date. The differences on flesh firmness at the harvest increased throughout the storage period. While the flesh firmness remained unchanged in 'SCS427 Elenise' ( 18 lb), it has decreased significantly on 'Cripps Pink' along the 8 months in CA cold storage. The rates of sugar increased and acidity decreased in the apples evaluated along the 8 months of storage, being higher in 'Crisp Pink' than in 'SCS427 Elenise'. Therefore, the differences regarding SSC/TA ratio gradually showed the tendency of reducing from harvest to the $6^{\text {th }}$ month of storage and disappeared after this time of storage. 'SCS427 Elenise' fruits did not develop symptoms of physiological disorders $\mathrm{CO}_{2}$ (data not shown) and superficial scald during the 8 months, while 'Cripps Pink' showed an increase in superficial scald symptoms along this period in CA cold storage. However, the development of fungal rots along CA cold storage was 
slightly higher on 'SCS427 Elenise' than on 'Cripps Pink' fruits. In general, 'SCS427 Elenise' fruits present potential storage superior to 'Cripps Pink', by better firmness conservation and less susceptibility to the physiological disorders related to superficial scald and $\mathrm{CO}_{2}$ damage, and their storage potential in CA seems to be greater than 8 months.

'SCS427 Elenise' apples show a slow flesh and juice browning because of the low oxidative reaction of their compounds (PRESTES, 2019). Therefore, in addition to the high potential for fresh fruit market, the variety SCS427 Elenise can promote changes on industries of apples minimally processed and apple juice in Brazil, whose depends on 'Gala' and 'Fuji' fruits nowadays.

\section{Pollination}

The varieties SCS431 Felix 1, SCS435 Felix 5 and SCS436 Felix 6 (experimental codes: 140/228, 140/494 and 140/144, respectively) have been indicated as good pollinizer varieties of 'SCS427 Elenise', based on flowering coincidence and pollination compatibility (BRANCHER, 2017).

\section{Availability of vegetative material for propagation}

The variety 'SCS427 Elenise' is under Plant Varieties Rights Application at SNPC/MAPA (Serviço Nacional de Proteção de Cultivares/Ministério da Agricultura, Pecuária e Abastecimento, Brazil). In order to get young trees, growers may contact the Epagri's licensees or Caçador Experimental Station at 55 (49) 35616800.

\section{Acknowledgements}

The authors thank Fischer S/A Agribusiness Company for the logistical support for conducting the trials in Fraiburgo, SC, in the advanced phase of the field test; Fapesc and ABPM for the financial support.

\section{References}

ARAÚJO, L.; MEDEIROS, H.A.; PASA, M.S.; SILVA, F.N. Doenças da macieira e da pereira. Informe Agropecuário, v.37, n. 291, p.6174, 2016. Disponível em: https://www. researchgate.net/publication/309414271_ Doencas_da_ macieira_e_da_pereira. Acesso em: 04 nov. 2019.

ARGENTA, L.C., SOUZA, F.D., NAVA, G., AMARANTE, C.V.T., ERNANI, P.R. Occurrence of postharvest physiological disorders in 'Fuji' apples in response to orchard fertilization with nitrogen and potassium. Acta Horticulturae, v.1012, p.1141-1148, 2013. DOI: 10.17660/ ActaHortic.2013.1012.154.

ARGENTA, L.C.; SCOLARO, A.M.T.; AMARANTE, C.V.T.; VIEIRA, M.J.; WERNER, S.S. Pre-harvest treatment of 'Gala' apples with 1-MCP and AVG - I: Effects on fruit maturation on the tree. Acta Horticulturae, v.1194, p.113-119. 2018. DOI: 10.17660/ ActaHortic.2018.1194.18.

BRANCHER, T.L. Genotipagem de alelos $S$ em macieira e sua utilização como ferramenta auxiliar ao melhoramento genético. Programa de Pós-Graduação em Produção Vegetal, Universidade do Estado de Santa Catarina. Udesc, Lages. 129 p. 2017. Disponível em: https://www.udesc.br/arquivos/ cav/id_cpmenu/1343/Disserta__o_ Thyana_15675399302331_1343.pdf. Acesso em: 02 nov. 2019.

DENARDI, F.; CAMILO, A.P.; KVITSCHAL, M.V. SCS417 - Monalisa: cultivar de macieira com boa adaptação climática no Sul do Brasil e resistência múltipla a doenças e pragas. Revista Agropecuária Catarinense, v.26, n.1, p.56-62, 2013. Disponível em: http:// publicacoes.epagri.sc.gov.br/index.php/ RAC/article/view/599. Acesso em: 03 nov. 2019.

DENARDI, F.; KVITSCHAL, M.V.; HAWERROTH, M.C. A brief history of the forty-five years of the Epagri Apple Breeding Program in Brazil. Crop Breeding and Applied Biotechnology, v.19, n.3, p.347-355, 2019. DOI: 10.1590/1984-70332019v19n3p47.

FACHINELLO, J.C.; PASA, M.S.; SCHMITZ,
J.D.; BETEMPS, D.L. Situação e perspectivas da fruticultura de clima temperado no Brasil. Revista Brasileira de Fruticultura, v.33, p.109-120, 2011. DOI: 10.1590/S010029452011000500014.

FERREIRA, D.F. Sisvar: a computer statistical analysis system. Ciência e Agrotecnologia, v.35, n.6, p.1039-1042, 2011. DOI: 10.1590/ S1413-70542011000600001.

FURLAN, C.R.C.; DANTAS, A.C.M.; DENARDI, F.; BECKER, W.F.; MANTOVANI, A. Resistência genética dos acessos do Banco de Germoplasma de Macieira da Epagri à Mancha Foliar de Glomerella (Colletotrichum gloeosporioides). Revista Brasileira de Fruticultura, v.32, n.2, p.507-514, 2010. DOI: 10.1590/s0100-29452010000200022.

KVITSCHAL, M.V.; COUTO, M.; BRANCHER, T.L. Variedades de macieira: Cenário Internacional e Nacional. Brazilian Journal of Development, v.5, n.10, p.18326-18334, 2019. DOI: 10.34117/bjdv5n10-091.

PRESTES, A. A. Avaliação do escurecimento enzimático em maçãs híbridas: potencial tecnológico e atividade antioxidante. Programa de Pós-Graduação em Ciência e Tecnologia de Alimentos, Universidade Estadual de Ponta Grossa. UEPG, Ponta Grossa. 109 p., 2019. Disponível em: https:// tede2.uepg.br/jspui/handle/prefix/2785. Acesso em: 02 nov. 2019.

SANSAVINI, S.; DONATI, F.; COSTA, F.; TARTARINI, S. Advances in apple breeding for enhanced fruit quality and resistance to biotic stresses: new varieties for the European market. Journal of Fruit and Ornamental Plant Research, v.12, p.1352, 2004. Disponível em: https://pdfs. semanticscholar. org/9d84/4f672d1 d 074 bcc 7548 bee 7 bc 2999715204 e 9 . pdf?_99838.1730487867.15965077461145762208.1596507746. Acesso em: 31 out. 2019.

SEZERINO, A.A. (Org.). Sistema de produção para a cultura da macieira em Santa Catarina. Florianópolis, SC, 2018. 136p. (Epagri. Sistema de Produção, 50). Disponível em: https://www.epagri.sc.gov.br/index. php/ solucoes/publicacoes/sistema-deproducao/. Acesso em: 29 out. 2019. 